\title{
ПРОБЛЕМНО-ДИАЛОГИЧЕСКАЯ ТЕХНОЛОГИЯ КАК СРЕДСТВО ФОРМИРОВАНИЯ КРИТИЧЕСКОГО МЫШЛЕНИЯ СТАРШИХ ШКОЛЬНИКОВ
}

Емельянова М.В. МОУ СОШ №27, Московская обл., г.о. Люберцы

Модернизация образовательной деятельности сегодня невозможна без использования системы менеджмента качества [2, с.156], предполагающей оценку качества знаний учащихся по изучаемым в школах дисциплинам. Инновационные процессы современного отечественного образования в контексте системно-деятельностного подхода потребовали пересмотра целевых ориентиров в определении образовательных результатов школьников, в качестве которых выступает система универсальных учебных действий. Успешное решение образовательных задач предполагает, что учащийся старших классов умеет ставить цели, владеет способами решения поставленной задачи или создает такие способы самостоятельно, умеет контролировать, оценивать и исправлять свою деятельность, что предполагает высокий уровень развития критического мышления.

Реализация эффективных педагогических технологий, обеспечивающих развитие критического мышления школьников старших классов, предполагает понимание сущности понятия «критическое мышление» с точки зрения его психолого-педагогических характеристик. В самом общем виде критическое мышление понимается как один из видов интеллектуальной деятельности человека, который характеризуется высоким уровнем восприятия, понимания, объективности подхода к окружающему его информационному полю [5, c.156]. Под критическим мышлением понимается «процесс, при помощи которого разум перерабатывает информацию, чтобы понять установившиеся идеи или создать новые, а также решить проблемы» [4, с.41]. По мнению И.С.Литвиновой, критическое мышление в педагогическом контексте представляет «один из видов продуктивного мышление, которое проявляется в специальных умениях и качествах личности и предполагает анализ, оценку и проверку объектов мышления с целью поиска истины, оптимальных путей решения проблем, совершенствования собственного мышления» [3, с.11-12].

Формирование навыков критического мышления, предусматривает не просто активный поиск старшеклассниками информации для усвоения, а соотнесение того, что они усвоили, с собственным опытом, а также сравнение 
усвоенного с другими исследованиями в данной области знания. В процессе мыслительной деятельности старшеклассники могут подвергать сомнению достоверность полученной информации, проверять логику доказательств, делать выводы, конструировать новые примеры и возможности решения проблемы [5, с.156]. Характеризуя критическое мышление Д. Клустер выделяет следующие его особенности: самостоятельность, отражающая способность к формированию идей и их анализу; осмысленность, непрерывность и продуктивность мыслительного процесса; формулировка вопросов и решение проблем, лежащих в основе критического мышления; нацеленность критического мышления на убедительную аргументацию, содержащую утверждение, доводы, доказательства и основание; социальные характеристики критического мышления, предполагающие процесс обмена мнениями с другими [1, c.37-39]. Опираясь на описанные ученым характеристики критического мышления, можно констатировать, что эффективным средством формирования критического мышления являются проблемно-диалогическая технология обучения.

Проблемно-диалогическая технология обучения традиционно осмысливается в контексте понимания сути более общего понятия «педагогическая технология», которая отражает систему функционирования всех компонентов педагогического процесса, построенной на научной основе, запрограммированной во времени и в пространстве, нацеленной на запланированный результат. Педагогическая технология как определенная область педагогической деятельности, с одной стороны, включает в себя ряд составляющих ее деятельностей и соответствующих технологий, с другой стороны, сама может быть включена как составная часть в деятельность (технологию) более широкого уровня [5,c. 38].

Технология проблемного обучения, используемая в практике преподавания учителями школ, предполагает создание под руководством учителя в сознании школьников проблемных ситуаций и организацию активной самостоятельной деятельности учащихся по их разрешению, в результате чего и происходит творческое овладение знаниями, умениями, навыками, развитие мыслительных способностей и овладение системой универсальных учебных действий. В основе проблемного обучения лежит особый вид проблемной мотивации, что требует адекватного конструирования дидактического содержания материала, который должен быть представлен как цепь проблемных ситуаций, которые могут быть различными по характеру 
неизвестного, по интересности содержания, по уровню проблемности, по виду рассогласования информации, по другим методическим особенностям.

Технология проблемного обучения предполагает реализацию комплекса проблемных методов обучения, основанных на создании проблемных ситуаций, активной познавательной деятельности школьников, нацеленной на поиск и решение сложных вопросов, требующих актуализации знаний на основе имеющегося опыта, анализа, умения видеть за отдельными фактами и явлениями их сущность и закономерности [5,c.40]. Российский ученый В.А. Метаева акцентирует внимание на рефлексивный характер развития критического мышления в процессе обучения школьников в условиях проблемного обучения, поскольку в нем содержатся процедурные элементы рефлексии: анализ, критика и построение новой нормы деятельности [3, с.20]. Развитие критического мышления в условиях реализации проблемно-диалогического обучения школьников предполагает развитие умения выделять причинно-следственные связи; рассматривать новые идеи в контексте уже имеющихся; отвергать ненужную или неверную информацию; понимать взаимосвязь различных частей информации; выделять ошибки в рассуждениях; уметь делать вывод о том, чьи идеи отражают текст; избегать категоричность в утверждениях; быть честным в своих рассуждениях; определять ложные стереотипы, ведущие к неправильным выводам; выявлять предвзятые суждения; уметь отличать факт, который всегда можно проверить, от предположения; подвергать сомнению логическую непоследовательность устной или письменной речи; отделять главное от несущественного в тексте или в речи [4, с. 156].

Проблемные ситуации лежащие в основе проблемного обучения характеризуют переживание интеллектуального затруднения и вопрос, заданный самому себе или другим о неизвестном знании, способе или необходимом условии действии [6, с.23-24]. Поэтому применение диалогических методов обучения при реализации проблемного обучения позволяют актуализировать познавательные вопросы в групповом обсуждении. Следует заметить, что методическими приемами создания проблемных ситуаций в диалогическом взаимодействии школьников являются: актуализация противоречий и их разрешение; соотношение противоречий с практической действительностью; изложение различных точек зрения на один и тот же вопрос; групповое рассмотрение явления с различных позиций; побуждение обучаемых делать сравнения, обобщения, выводы, сопоставлять факты; постановка конкретных вопросов на обобщение, 
конкретизацию, логику рассуждений; определение проблемных теоретических и практических заданий; использование задач с недостающими или избыточными исходными данными, с неопределенностью в постановке вопроса, с заведомо допущенными ошибками [6, с. 27].

Вывод. Реализация технологии проблемно-диалогического обучения школьников старших классов предполагает использование широкого спектра проблемных ситуаций; приоритетной формой диалогического взаимодействия в образовательном процессе является «учитель - группа», что создает широкий спектр коммуникативных ситуаций, что требует от школьников умения участвовать в диалоге, дискуссиях, аргументировано отстаивать собственную точку зрения, строить содержательное, развернутое монологическое высказывание. Школьники старших классов в диалоге овладевают умением не только понимать цель своего обучения, но и самостоятельно ее ставить, определять конкретные задачи, программировать собственную мыслительную деятельность, отбирать адекватные средства достижения цели, определять последовательность мыслительных действий, что в свою очередь должно способствовать развитию их критического мышления.

\section{Список литературы}

1. Клустер Д. Что такое критическое мышление? // Перемена. 2001. № 3. C. 36-40.

2. Кузнецова Н.В., Ли Ю.С. Система менеджмента качества и использование инноваций в вузовском образовательном пространстве.// Социально-психологические аспекты практики социальной работы. Сборник научных статей. (ИПССО ГАОУ ВО МГПУ; РГСУ филиал в г. Люберцы) / Отв. ред.: Овчаренко Л.Ю., Тютченко А.М. Ред.-сост. Дорошенко Т.Н. М.: Издательство «Перо», 2016.- с.155-160.

3. Литвинова И.С. Деятельность учителя гуманитарных дисциплин по развитию критического мышления старшеклассников: дис. ... кандидата педагогических наук: 13.00.01. Тула, 2005.

4. Метаева В.А. Методологические и методические основы рефлексии: Учебное пособие. Екатеринбург, 2006.

5. Селевко Г.К. Энциклопедия образовательных технологий. В 2-х т. Т. 1. М.: Народное образование, 2005.

6. Федотова Г.А., Игнатьева Е.Ю. Профессионально-ориентированные технологии обучения в высшей школе: Учеб. пособие. Великий Новгород, 2010. 